\title{
PRODUCTIVITY AND QUALITY OF BAGGING FRUIT OF HYBRID TOMATOES
}

\section{PRODUTIVIDADE E QUALIDADE DE FRUTOS ENSACADOS E HIBRIDOS DE TOMATE}

\author{
Raoni Terra de Oliveira BORGES ${ }^{1}$; Roberta Camargos de OLIVEIRA ${ }^{2}$; \\ Fabio Teixeira LUCAS ${ }^{3}$; José Magno Queiroz LUZ ${ }^{4}$; Regina Maria Quintão LANA ${ }^{4}$ \\ 1. Doutorando em Agronomia Instituto de Ciências Agrárias da Universidade Federal de Uberlândia-ICIAG-UFU, Uberlândia, MG, \\ Brasil. raoniterra@ hotmail.com; 2. Pós-doutoranda na Universidade Federal de Uberlândia-ICIAG-UFU, Uberlândia, MG, Brasil; 3 \\ Doutor, Engenheiro Agrônomo da Prefeitura Municipal de Uberaba, Uberaba-MG; 4. Professor do ICIAG-UFU, Uberlândia, MG, \\ Brasil.
}

\begin{abstract}
Tomato cultivation is challenging due to the high susceptibility to various pests and diseases. Fruit borer insects make fruits unfeasible for commercialization because this favors colonization by pathogens. The loss due to borers can be avoided by bagging the bunches of fruit, helping the conventional crop to be more sustainable, reduce the use of pesticides, reduce the residue in fruits and improve the quality of life of rural workers, by less exposure to agrochemicals and poisoning problems. The results are products of better quality and with the possibility of better profitability. The objective of this study was to evaluate the efficiency of tomato bagging in the control of fruit borer insects, and its effects on lycopene content, taste, productivity and profitability. The experiment was conducted in a field in the municipality of Uberaba-MG, from November 2016 to September 2017. The experimental design was a randomized block design, in a 3 x 5 factorial, with four replications. The factors consisted of three tomato hybrids: Dominador (salad), Ravena (Italian) and Carina Star (Santa Cruz), and fruit bagging types, made by TNW (tissue-non-woven), tulle, organza, brown craft and a control, without fruit bagging. The decision of bagging use depends on the pest incidence in the area and the change in the agronomic characteristics of the tomato. The organza and tulle fruits bagging reduce the incidence of borer insects, relative to the control, in the cultivation in spring-summer. The Dominador presents higher brix content among the evaluated hybrids. Carina Star, when bagged with organza, produces fruits with higher levels of lycopene, and is $116 \%$ superior to the other cultivars. From the second harvest, organza fabric is the most profitable bagging, since it is the only one that can be reused several times and is therefore more sustainable.
\end{abstract}

KEYWORDS: Solanumlycopersicum. Alternative control of insects. Sustainability.

\section{INTRODUCTION}

Tomatoes (Solanum lycopersicum) is the second most consumed and appreciated vegetable in many countries (MEENA et al., 2017). The fruits contain nineteen amino acids, hydrophilic antioxidants (anthocyanins, phenolics, vitamin C and flavonols), lipophilic antioxidants (lycopene, $\beta$ carotene and tocopherols), macro and micronutrients (NASIR; HUSSAIN; JABBAR, 2015). All of these compounds are good for health, and prevent obesity, hyperglycemic and cardiovascular disorders, and cancer (VIUDA-MARTOS, et al., 2014; PERVEEN et al., 2015). Biological and physicochemical properties, such as being a source of the neurotransmitter serotonin (HANO et al., 2017), increase fruits consumption of these fruits (KLUNKLIN; SAVAGE, 2017) and consequently increases crop demand as well.
Brazilian tomato production in 2017 was estimated at 4.5 million tons of fruit (IBGE, 2018). In addition to the nutritional and economic aspects, the culture has a social relevance due to the generation of employment and being a source of income for several families (PEIXOTO et al., 2017; PRAMANIK; MOHAPATRA, 2017), which strengthens family farming, reducing rural exodus and promotes regional development (CARVALHO et al., 2014).

Tomato cultivation is complex and highly demanding in inputs and labor (FILGUEIRA, 2012). Among the cultivation aspects, phytosanitary substantially reflects tomato yield and quality since the species is host to a wide range of pathogens and insects, creating direct or indirect damages from the seedlings phase to the harvest season (GOMES; CASTRO, 2017) with incidence and degree of damage depending on the region and cultivation 
time (MOURA; MICHEREFF FILHO; GUIMARAES, 2014).

The phytosanitary management in the crop is carried out primarily with agrochemicals in frequent applications. However, continuous use may lead to a lack of attention with this hazard, with consequent reduction of care with the environment, non-use of personal protective equipment and noncompliance with the product's grace period (CASTRO; DAIUTO; VIEITES, 2016).

On the other hand, consumers' demand for quality, appearance, and flavored foods is increasing, and fruits produced in an economically viable, socially just, and environmentally correct manner is a goal namely described as Integrated Production (PORTO; SOARES, 2012; VEDANA; VIEIRA; ITAVO, 2016).

The new production systems with use of correct inputs can reduce the food and environmental contamination risks and reduce the intoxication of the field worker, and are seen as strategies adding product value, and serve market niches that require foods certification produced with sustainability (SILVA; CALEMAN, 2015).

Among insects control alternatives, the tomato bunch bagging is being studied because it promotes a physical barrier that aims for insect and pathogens damage reduction and conservation of high fruits quality (COSTA et al., 2017). Bagging is a common practice in fruit growing especially on crops such as mango (NAGAHARSHITHA; VIMALA; HALDANKAR, 2014; RATHORE; PAL, 2016; REHMAN et al., 2015), apple (MATSUMOTO et al., 2018; FENG et al., 2014), guava (NANDI et al., 2016) and peach (ZHANG et al., 2015; GUIXIANG et al., 2017).

There are various types of fruit bags which can change the microclimate inside the bag (LIMA et al., 2018) and promote different effects on fruit growth and ripening (WANG et al., 2017). In order to embrace the technique in vegetables, the cost/benefit must be investigated since bagging is laborious (SHARMA; REDDY; JHALEGAR, 2014) and can be deleterious to the characteristics essential for commercialization (VENDRUSCOLO et al., 2017).

The objective of this study was to evaluate some types of packaging in the bagging of tomato fruits during their development in order to maintain quality (control of fruit borer insects, lycopene content, taste, productivity and profitability) of Ravena, Dominador and Carina Star varieties.

\section{MATERIAL AND METHODS}

The experiments were conducted in the rural area of the municipality of Uberaba in the state of Minas Gerais (Latitude: -19.703280, Longitude: 47.997107). A first experiment (spring-summer) was conducted between November 2016 and February 2017 and another between March 2017 and August of the same year (autumn-winter). The first experiment was lost due to phytosanitary and physiological problems; however, the percentages of losses caused by borers were recorded in the first two bunches, which were bagged when the fruits were between 1.5 and $3.0 \mathrm{~cm}$ in diameter, as proposed by Filgueiras (2016).

According to Köppen classification, the climate is Aw-tropical, with dry winter and rainy summer. The rainfall was measured using a rain gauge installed at the experiment site and the average temperatures were measured at a meteorological station of the National Institute of Meteorology of Uberaba, as shown in Figure 1.

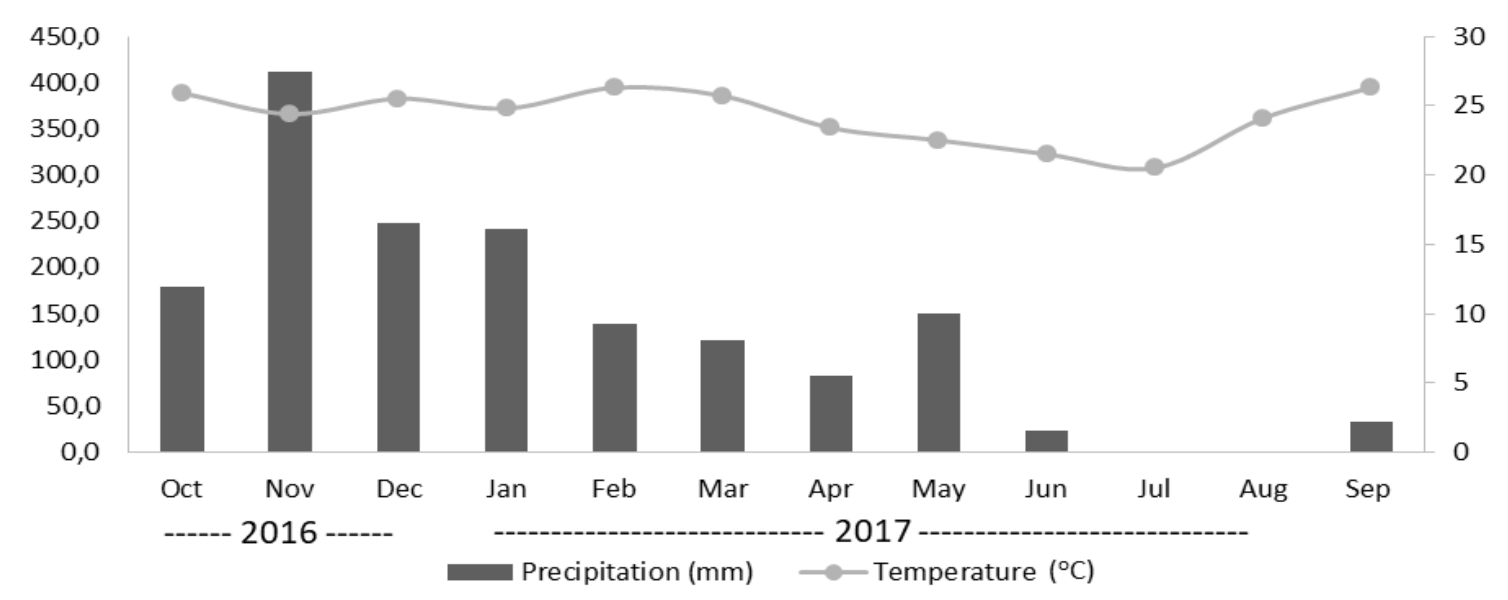

Figure 1. Climatic conditions at the experimental areas 
Productivity and quality...

The experimental design was a randomized complete block with a $3 \times 5$ factorial scheme, replicated four times. The treatments consisted of three hybrids (Dominador (salad), Ravena (Italian) and Carina Star (Santa Cruz)) and five fruit bagging (TNW (tissue-non-woven), tulle, organza, brown craft and bunches without bagging). The dimensions of the bags were $30 \times 40 \mathrm{~cm}$ and sewn by domestic sewing machine, except for the brown craft that was stapled. Each useful plot consisted of three plants, with each plant being conducted with five bunches.

The area planted was limed a year earlier and Brachiaria decumbenswas sown with this species until the preparation for the experiment. The preparation of the land was done on March 1, 2 and 3 of 2017 with costal brush cutter without the soil stirring, and the straw remained on the ground.

The hybrids were sown on April 2 in trays of 128 cells using a substrate composed of sphagnom peat, vermiculite, dolomitic limestone, agricultural gypsum and NPK fertilizer. The trays were kept for 30 days in a nursery planted against aphids.

The soil of the area was classified as Latosol, with a clayey texture. Soil chemical analysis performed before soil preparation at $0-20$ $\mathrm{cm}$ depth showed the following results: $\mathrm{P}=8.10 \mathrm{mg}$ $\mathrm{dm}^{-3} ; \mathrm{K}=0.34 \mathrm{cmol}-\mathrm{dm}^{-3}, \mathrm{pH}=6.3 ; \mathrm{Ca}^{2}+=$ $4.04 \mathrm{cmolc} \mathrm{dm}^{-3} ; \mathrm{Mg}^{2+}=0.49 \mathrm{cmolc} \mathrm{dm}{ }^{-3}, \mathrm{Al}^{3+}=0$ cmolc dm ${ }^{-3}, \mathrm{~T}=8.07 \mathrm{cmolc} \mathrm{dm}^{-3}$; Base Saturation= $60.30 \%$, organic matter $=2.86 \mathrm{dag} \mathrm{kg}^{-1}$.

Pits were opened with $25 \mathrm{~cm}$ diameter and $40 \mathrm{~cm}$ depth of soil drill and were fertilized with 200 grams of natural thermophosphate and 3 liters of tanned bovine manure one week before transplanting the seedlings. Cover fertilizations were done at 15 grams per plant with the NPK formulation 20-00-20 at 15, 30, 45 and 60 days after transplanting (DAT) and at 20 grams per plant with NPK 10-00-20 formulation at 75, 90, 105 and 120 DAT (ALVARENGA, 2013).

The seedlings were planted on May 2 of 2017 spaced $0.60 \mathrm{~m}$ between plants and $1.7 \mathrm{~m}$ between lines of plants. The plants were conducted with only one stem (single plants), tied with galvanized plain wire ties n. 1.2 to $1.7 \mathrm{~m}$ high. The lines of 50 meters each had eucalyptus mortars treated at both ends, and between them, bamboo every 3 meters. The irrigation system used was by drip irrigation, with two hoses per line and drippers every $20 \mathrm{~cm}$ per hose.
BORGES, R. T. O.

No pesticides were used, even not including the natural insecticides allowed in organic agriculture, such as neem oil (Azadirachta indica) and smoke syrup (Nicotianata bacum L.), in order to avoid interference with the incidence of insect borer. However, for control of virus-transmitting aphids, adhesive traps with color attraction were used, with the yellow plastic canvas for whitefly (Bemisia tabaci) and aphids (Myzus persicae), and blue plastic canvas for attracting thrips (Frankliniella sp.).

The stripping, tutoring and fruit thinning were done weekly and manually, always with disinfected latex gloves, with a $15 \%$ benzalkonium chloride solution acting as fungicide, bactericide and viricide. After the thinning of the flowers were left, five bunches per plant were chosen and these were bagged as soon as all the flowers were already fertilized.

For the evaluation of the total soluble solids content, a manual refractometer was used, with the results expressed in degree brix. For the lycopene content, we followed the methodology proposed by Nagata and Yamashita (1992), using a spectrophotometer. Carina Star and Ravena hybrids began to be harvested 105 days after sowing (DAS), and Dominant, 115 DAS. The cost of production of tomatoes per plant was estimated according to the producer's management and the local price of inputs (Table 1). Whole bunches were harvested when fully matured. After the harvest, the broached fruits were counted and thus the percentage of loss by the pests was determined. For the economic evaluation, the undamaged tomatoes of each cluster were weighed in order to find the productivity per plant and multiplied by the value sold in the market, discounting production costs (Tables 1, 2 and 3) and, consequently, reaching profitability (Table 4).

The profitability was obtained by multiplying the productivity per plant with the sales value in the market. The value used was the same paid to family farmers participating in the 2017 Food Acquisition Program (PAA). Regardless of the classification of the fruits, for this program the value of the tomato kilo is $\mathrm{R} \$ 2.24$ throughout the year.

The data obtained were submitted for analysis of variance (test F). Therefore, the Tukey test was used for all factors evaluated. The SISVAR program at the 0.05 level of significance performed the analyses. 
Table 1. General cost of production of tomatoes per plant

\begin{tabular}{ll}
\hline Inputs andservices & Plant $\operatorname{cost}^{-1}(\mathrm{R} \$)$ \\
\hline Tractor & 0.01 \\
Limestone & 0.05 \\
FertilizerPlanting & 0.30 \\
FertilizerCoverage & 0.24 \\
Clearing & 0.09 \\
Coloredcanvas & 0.14 \\
Disinfectant & 0.07 \\
Grease & 0.03 \\
Latexgloves & 0.09 \\
Structure & 0.81 \\
Irrigation & 0.62 \\
Total & 2.45 \\
\hline
\end{tabular}

Table 2. Cost of seedlings of each hybrid per plant

\begin{tabular}{lc}
\hline Hybrids & Plantcost $^{-1}(\mathrm{R} \$)$ \\
\hline Carina Star & 0.49 \\
Ravena & 0.54 \\
Dominador & 0.64 \\
\hline
\end{tabular}

Table 3. Cost to bag five bunches of tomato per plant

\begin{tabular}{ll}
\hline Bagging & Plantcost $^{-1}(\mathrm{R} \$)$ \\
\hline Organza & 5.90 \\
Tulle & 2.00 \\
TNW & 2.00 \\
Brown craft & 1.20 \\
Control & 0.00 \\
\hline
\end{tabular}

Table 4. Estimation of the profitability per plant of each hybrid with its respective bagging

\begin{tabular}{llllll}
\hline Bagging/Hybrids & Carina Star & \multicolumn{2}{l}{ Dominador } & Ravena \\
\hline & $\begin{array}{l}\text { First } \\
\text { harvest }\end{array}$ & $\begin{array}{l}\text { Second } \\
\text { harvest }\end{array}$ & $\begin{array}{l}\text { First } \\
\text { harvest }\end{array}$ & $\begin{array}{l}\text { Second } \\
\text { harvest }\end{array}$ & $\begin{array}{l}\text { First } \\
\text { harvest }\end{array}$ \\
\hline Brown craft & & & & R\$ & \\
TNW & 5.13 & 5.13 & 7.94 & 7.94 & 6.80 \\
Tulle & 4.08 & 4.08 & 7.29 & 7.29 & 5.93 \\
Organza & 4.88 & 4.88 & 7.44 & 7.44 & 6.13 \\
Control & 2.18 & 8.08 & 2.17 & 8.07 & 2.42 \\
\hline
\end{tabular}

\section{RESULTS AND DISCUSSION}

There was no difference between hybrids in relation to the percentage of fruit-borers for springsummer and autumn-winter (Figure 2A and B). The incidence of drills in the experimental area was low in spring-summer, with a percentage of borer incidences between 17 and 29\% of the fruits (Figure $2 \mathrm{~A})$. In the autumn-winter, due to the pronounced cold in the cultivation period, only $1.7 \%$ of the fruits of the Dominador hybrid showed borer fruit (Figure 2B).
In the spring-summer, fruit bagged with Organza and Tule showed lower fruit losses, 6.6 and $11.6 \%$ of the fruits produced, respectively, which represented fruit losses 6.3 and 3.5 times lower than fruits not bagged (control) (Figures 3A). In autumnwinter, there was a low infestation of insect borers, and only $1.7 \%$ of fruit losses were found. Therefore, the choice for bagging depends on the season, which corroborates with the literature (FILGUEIRAS et al., 2017). 


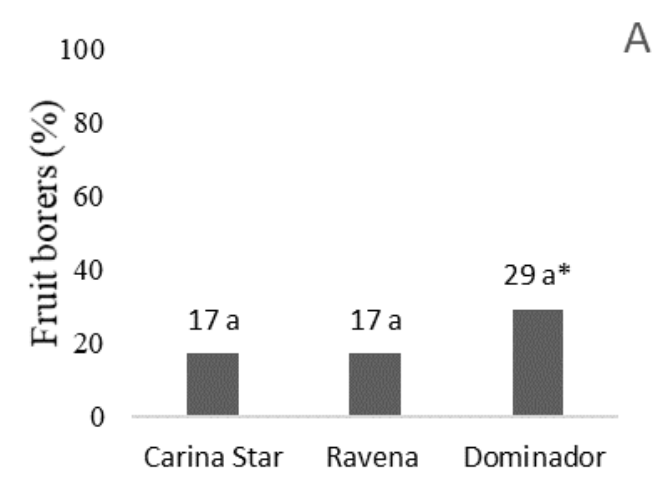

Hybrid
A 100

80

60

40

20

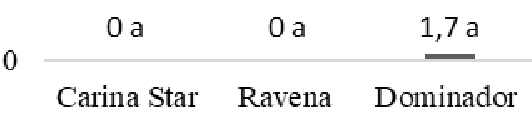

Hybrid

Figure 2. Average percentage of hybrids efficiency on fruit borers control in spring-summer (A) and autumnwinter (B)

*The values followed by the same letter do not differ statistically by the Tukey test at 5\% probability



Figure 3. Average percentage of bagging efficiency on fruit borers control in spring-summer (A) and autumnwinter (B)

*The values followed by the same letter do not differ statistically by the Tukey test at $5 \%$ probability

In a period of climatic conditions favorable to the multiplication of insects, such as summer, bagging constitutes an important strategy for reducing losses by drills, according to the results. However, it is important to remember that the bagging keeps the heat in the fruit area, which can cause beneficial effects in the fruit development, especially the related to metabolism and gas exchange.

Thus, the physical, chemical, biochemical and physiological changes in the ripening of tomatoes are controlled by respiration and ethylene levels (FAGUNDES et al., 2015), which can be significantly influenced according to the microclimate inside the bags. According to Colombié et al. (2017), metabolic fluxes such as respiration at the maturation stage are involved in the degradation of starch and cell walls, which can improve tomato quality through a higher ratio between sugars and acids (BERTIN; GÉNARD, 2018).

The ideal temperature for insect development generally ranges from 15 to $38{ }^{\circ} \mathrm{C}$. Below $15{ }^{\circ} \mathrm{C}$ the insects enter into temporary hibernation (GALLO et al., 2002). In June and July 2017, minimum temperatures were observed reaching below $10^{\circ} \mathrm{C}$, which is below the minimum threshold temperature favorable to the development of insects, and explains the low incidence of pest in autumn and winter (Figure 3B).

Filgueiras et al. (2017) proposed to bag the fruits when they present between 1.5 and $3.0 \mathrm{~cm}$ in diameter, which was done in the first experiment. However, since the sheaths were completely closed, a control of the fruit borers was expected to be close to $100 \%$, but this was not observed. One of the reasons may be the oviposition of the moths before the fruits reach their size to be bagged. 
As for productivity, in the spring-summer experiment the high incidence of physiological problems and high incidence of black point of tomato (Alternaria solani) and other pathogens made it impossible to conduct the test until the end of the crop cycle and did not allow for the analysis of productivity and profitability.
BORGES, R. T. O.

In the autumn-winter experiment there was a significant interaction between the type of bagging and hybrids for fruit yield, Brix and lycopene content (Figure 4, 5 and 6). The productivity of tomato hybrids packed with Organza did not differ between them. In the other types of packaging, Dominador and Ravena were the most productive hybrids (Figure 4).



Figure 4. Productivity $\left(\mathrm{kg} \mathrm{plant}^{-1}\right)$ of tomato fruit according to the type of bagging and hybrid

*Means followed by lower case letters between hybrids and upper case letters between types of bagging do not differ statistically according to Tukey test $(\mathrm{P}<0.05)$

The organza was favorable and the TNW unfavorable to fruit productivity of the Carina hybrid, compared to the control. For the Dominador and Ravena hybrids, the yield of the packed fruits did not differ from the control (Figure 4), corroborating with the results of Lebedenco, Auad and Kronka (2007) and Fialho (2009) who verified that the average productivity of bagged tomatoes remained close to the average of the non-bagged ones.

The genetic expression of hybrids varied according to the material used in the packaging due to changes in metabolic processes, such as the suppression of gene expression related to lignin synthesis, which significantly improves quality and appearance aspects (MISHRA; PATHAK; CHAUDHARY, 2017; WANG et al., 2017; COSTA et al., 2017).

Regarding the soluble solids content (brix), there was no difference between the packages in the Carina Star hybrid (Figure 5). The Dominador presented the highest brix, a response to the genetic characteristic, since this hybrid is later than the others, having more time to accumulate sugars during the fruit development.

The Brown craft and Organza packages were the most favorable to the accumulation of soluble solids for the Dominador, and the brix of the fruits packed with Organza was $23.42 \%$ higher than the control (Figure 5). However, the brix of the fruits bagged with brown craft did not differ in relation to the control for the hybrid Ravena, and the others bagging were not favorable to this hybrid.

Regarding the variations within each type of bagging, there were no differences between the hybrids when bagged with brown craft, the Ravena hybrid presented lower ${ }^{\circ}$ brix in fruits bagged with Organza, TNW and Tule, whereas the fruits of the same hybrid presented higher brix content among the non-bagged hybrids.

It was observed that even though the brown craft was a non-translucent material, photosynthesis was not impaired. In addition, the mature fruits were within the standard proposed by Alvarenga (2013), whose total soluble solids values are between 3.5 and 6.0 degrees brix. Islam et al. (2017) observed that brown craft to bag fruits presented better shelf life, lower weight loss and good physical quality compared to non-bagged fruits (control).

There was no difference in the lycopene content between the bagging types for the Ravena and Dominador hybrids. For Carina, the main content was related to bagging with Organza (Figure $6)$. 


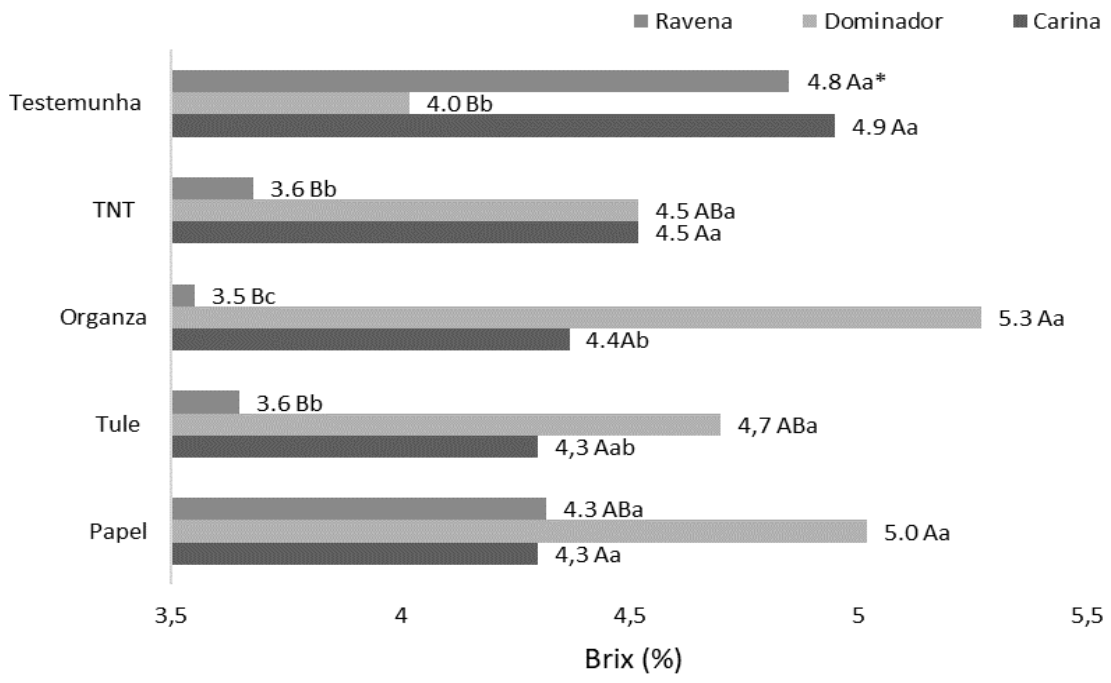

Figure 5. Brix (\%) of tomato fruit according to the type of bagging and hybrid

* Means followed by lower case letters between hybrids and upper case letters between types of bagging do not differ statistically according to Tukey test $(\mathrm{P}<0.05)$

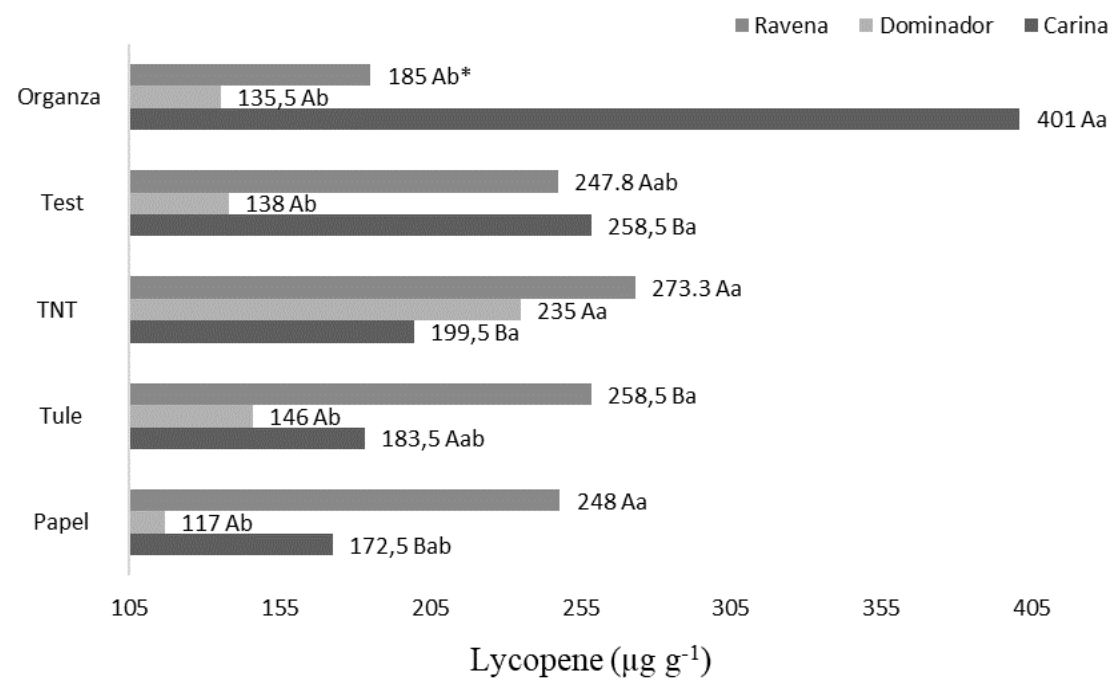

Figure 6. Lycopene content ( $\mu \mathrm{g} \mathrm{g}^{-1}$ ) of tomato fruit according to the type of bagging and hybrid

*Means followed by lower case letters between hybrids and upper case letters between types of bagging do not differ statistically according to Tukey test $(\mathrm{P}<0.05)$

The Dominador was the hybrid with lower values of lycopene, regardless of the type of bagging. The Carina bagged with Organza has 2.95 times more lycopene than the Dominador with the same bagging. The Carina bagged with Organza reaches a lycopene content $155 \%$ higher than the same hybrid without bagging.

The volatile composition of the fruits may be influenced by environmental factors, either directly due to changes in their synthesis rate or indirectly due to effects on ripening processes (KYRIACOU; ROUPHAEL, 2017; BERTIN; GÉNARD, 2018). The materials of the bags used to protect the tomatoes fruits differ in composition, thickness, color, opacity, degree of perforation, transmissivity of radiation, number of layers, which are essential characteristics for temperature control (LIMA et al., 2018). Therefore, the microclimate formed inside the bags in interaction with the genetic factors led to the differences found in this present study.

The use of bagging fruits is a viable method of comparison with the use of agrochemicals (LEITE et al., 2014; RUSIN et al., 2015; FILGUEIRAS et al., 2017). It was observed that the profitability of the control in the three hybrids was superior to the other treatments, but it is worth noticing that there were no significant losses caused by the fruit borers in the control. Taking into account the results obtained by Fialho (2009), which 
show losses about $30 \%$ in production when the fruits are not bagged, it can be stated that the use of the fruit bagging against the fruit-borer can be profitable, even using more expensive materials such as Organza.

Profitability was initially lower when Organza was used as it was more expensive and resistant (Table 4). In this sense, we should consider the choice of this material as an investment since it can be reused after sanitizing in water with $1 \%$ sodium hypochlorite (MACHADO et al., 2001).

Brown craft, despite being the cheapest material at a cost of $\mathrm{R} \$ 0.24$ a unit, is a disposable material, which ends up not being advantageous in the following crops, besides increasing the solid waste. Tule and TNW are not sufficiently resistant to reuse for more than two harvests, and need to be replaced every two harvests.

The use of bagging as a mechanical barrier may or may not maintain the chemical characteristics of tomato fruits, such as total soluble solids, $\mathrm{pH}$, titratable acidity, total carotenoids, $\beta$ - carotene and lycopene. Fialho (2009), Ferreira et al. (2010), Leite et al. (2014), Filgueiras (2016) and Pastori et al. (2017) reported similar results between bagged and unbagged fruits. As shown in the present study, it is necessary to observe the interaction between the hybrid and the type of packaging in order to determine the best choice.

\section{CONCLUSIONS}

The organza and tulle fruits bagging reduce the incidence of borer insects, relative to the control, in the cultivation in spring-summer.

The Dominador presents higher brix content among the evaluated hybrids.

Carina, when bagged with organza, produces the fruits with higher levels of lycopene.

From the second harvest, Organza fabric is the most profitable bagging, since it is the only one that allows to be reused several times and is therefore more sustainable.

RESUMO: O cultivo do tomateiro é desafiador devido a suscetibilidade a diversas pragas e doenças. Os insetos broqueadores de frutos inviabilizam os frutos para comercialização, além de favorecerem a colonização por patógenos. As perdas por brocas podem ser evitadas com o ensacamento dos cachos, podendo ser, inclusive, um aliado ao cultivo convencional por permitir maior sustentabilidade dos sistemas, com menor uso de defensivos, menor resíduo nos frutos e melhoria na qualidade de vida dos trabalhadores rurais, pela menor exposição a agroquímicos e problemas de intoxicações, resultando em produtos de melhor qualidade e com possibilidade de melhor rentabilidade. Com isso, objetivou-se avaliar a eficiência do ensacamento de cachos de tomate, no controle dos insetos broqueadores de frutos, os seus efeitos no teor de licopeno, no sabor, na produtividade e na rentabilidade. O experimento foi conduzido em campo no Município de Uberaba-MG, no período de novembro de 2016 a setembro de 2017. O delineamento experimental foi o de blocos ao acaso, em esquema fatorial $3 \times 5$, com quatro repetições. Os fatores constituíram de três híbridos de tomate: Dominador (salada), Ravena (italiano) e Carina Star (Santa Cruz) e os invólucros foram confeccionados com TNT (tecidonão-tecido), tule, organza e papel pardo. $\mathrm{O}$ uso do ensacamento depende da incidência da praga na área e da alteração nos caracteres agronômicos do tomateiro. O ensacamento dos frutos com organza e tule reduzem a incidência de insetos broqueadores, com relação a testemunha, no cultivo em primavera-verão. O Dominador apresenta maior teor de brix entre os híbridos avaliados. Carina Star, quando ensacado com organza, produz os frutos com maiores teores de licopeno. A partir da segunda safra, o tecido organza é o ensacamento mais rentável, pois é o único que permite ser reutilizado por várias vezes, sendo, portanto, mais sustentável que os demais.

PALAVRAS-CHAVE: Solanumlycopersicum.Controle alternativo de insetos. Sustentabilidade.

\section{REFERENCES}

ALVARENGA, M. A. R. Tomate: produção em campo, em casa-de-vegetação e hidroponia. Lavras: UFLA, 2013. 25-27 p.

BERTIN, N.; GÉNARD, M. Tomato quality as influenced by preharvest factors. Scientia Horticulturae, v. 233, p. 264-276, 2018. https://doi.org/10.1016/j.scienta.2018.01.056 
CASTRO, R. S. D.; DAIUTO ER, VIEITES RL. Análise microbiológica e de pesticidas em tomates consumidos em restaurantes em Botucatu-SP. Nativa, v.4, n.6, p.398-402, 2016. https://doi.org/10.14583/23187670.v04n06a09

CARVALHO, C. R. F.; PONCIANO, N. J.; SOUZA, P. M.; SOUZA, C. L. M.; SOUSA, E. F. Economic feasibility and risk of tomato production in the municipality of Cambuci/RJ, Brazil. Ciência Rural, v. 44, n. 12, p. 2293-2299, 2014. https://doi.org/10.1590/0103-8478cr20131570

COLOMBIÉ, S.; BEAUVOIT, B.; NAZARET, C.; BÉNARD, C.; VERCAMBRE, G.; LE GALL, S.; BIAIS, B.; CABASSON, C.; MAUCOURT, M.; BERNILLON, S.; MOING, A.; DIEUAIDE-NOUBHANI, M.; MAZAT, J. P.; GIBON, Y. Respiration climacteric in tomato fruits elucidated by constraint-based modelling. New Phytologist, v. 213, p. 1726-1739, 2017. https://doi.org/10.1111/nph.14301

COSTA, A. C.; RAMOS, J. D.; MENEZES, T. P.; LAREDO, R. R.; DUARTE, M. H. Quality of pitaia fruits submitted to field bagging. Revista Brasileira de Fruticultura, v. 39, n. Spe., (e-377), 2017. https://doi.org/10.1590/0100-29452017377

FAGUNDES, A. C.; MORAES, A. K.; PÉREZ-GAGO, B. M. B.; PALOU, B. L.; MARASCHIN, C. M.; MONTEIRO, A. A. R. Effect of active modified atmosphere and cold storage on the postharvest quality of cherry tomatoes. Postharvest Biology and Technology, v. 109, p. 73-81, 2015.

https://doi.org/10.1016/j.postharvbio.2015.05.017

FENG, F. J.; LI, M.; MA, F. W.; CHENG, L. The effects of bagging and debagging on external fruit quality, metabolites, and the expression of anthocyanin biosynthetic genes in 'Jonagold' apple (Malus domestica Borkh.), Scientia Horticulturae, v. 165, n. 22, p.123-131, 2014. https://doi.org/10.1016/j.scienta.2013.11.008

FERREIRA, S. M. R.; QUADROS, D. A.; KARKLE, E. N. L.; LIMA, J. J.; TULLIO, L. T.; FREITAS, Y. R. J. S. Qualidade pós-colheita do tomate de mesa convencional e orgânico. Ciência e Tecnologia de Alimentos, v. 30, n. 4, p. 858-864, 2010. https://doi.org/10.1590/S0101-20612010000400004

FIALHO, A. Ensacamento de frutos no cultivo orgânico de tomateiro. 2009. 59 f. Dissertação (Mestrado em Ciências Agrárias) - Universidade Federal de Minas Gerais, Minas Gerais, 2009.

FILGUEIRA, F. A. R. Novo manual de olericultura: agrotecnologia moderna na produção e comercialização de hortaliças. Viçosa: UFV, 2012. 194 p.

FILGUEIRAS, R. M. C. Tecido-não-tecido (TNT) para ensacamento de cachos visando controle de broqueadores de frutos do tomateiro (Solanum lycopersicum L.). 2016. 65 f. Dissertação (Mestrado em Agronomia/Fitotecnia) - Universidade Federal do Ceará, Fortaleza, 2016.

FILGUEIRAS, R. M. C.; PASTORI, P. L.; PEREIRA, F. F.; COUTINHO, C. R.; KASSAB, S. O.;BEZERRA, L. C. M. Agronomical indicators and incidence of insect borers of tomato fruits protected with non-woven fabric bags. Ciência Rural, v. 47, n. 6, 2017. https://doi.org/10.1590/0103-8478cr20160278

GALLO, D.; NAKANO, O.; SILVEIRA NETO, S.; CARVALHO, R. P. L.; BAPTISTA, G. C.; BERTI FILHO, E.; PARRA, J. R. P.; ZUCCHI, R. A.; ALVES, S. B.; VENDRAMIM, J. D.; MARCHINI, L. C.; LOPES, J. R. S.; OMOTO, C. Entomologia Agrícola. Piracicaba: FEALQ, 2002. 920 p.

GOMES, S. K. S.; CASTRO, M. T. Monitoramento de insetos em plantio de tomate com adubação silicatada, Biodiversidade, v. 16, n. 3, p. 60, 2017.

GUIXIANG, L.; ZHANG, A.; WANG, X.; YIN, X.; DONG, X. E.; LIU, W.; ZHANG, Y.; TENG, X.; ZANG, S. Effects of Bagging with Paper Bags and Non-woven Bags on Flavor Compounds of Feicheng Peach.

Agricultural Science \& Technology, v. 18, p. 7, 2017. 
ISLAM, M. T.; SHAMSUZZOHA, M.; RAHMAN, M. S.; HAQUE, M. M.; ALOM, R. Influence of preharvest bagging on fruit quality of mango (Mangifera indica L.) cv. Mollika. Journal of Bioscience and Agriculture Research, v. 15, n. 1, p. 1246-1254, 2017. https://doi.org/10.18801/jbar.150117.153

HANO, S.; IMOTO, N.; ITO, A.; IMANISHI, S.;ASO, H.; KANAYAMA, Y. Serotonin content in fresh and processed tomatoes and its accumulation during fruit development. Scientia Horticulturae, v. 214, n. 5, p.107113, 2017. https://doi.org/10.1016/j.scienta.2016.11.009

KLUNKLIN, W.; SAVAGE, G. Effect on Quality Characteristics of Tomatoes Grown Under Well-Watered and Drought Stress Conditions. Foods, v.6, n. 56, p. 1-10, 2017. https://doi.org/10.3390/foods6080056

KYRIACOU, C.; ROUPHAEL, Y. Towards a new definition of quality for fresh fruits and vegetables. Scientia Horticulturae, v. 234, p. 463-469, 2017. https://doi.org/10.1016/j.scienta.2017.09.046

LEBEDENCO, A.; AUAD, A. M.; KRONKA, S. N. Métodos de controle de lepidópteros do tomateiro (Lycopersiconesculentum Mill.). Acta Scientiarum Agronomy, v. 29, n. 3, p. 339-344, 2007. https://doi.org/10.4025/actasciagron.v29i3.278

LEITE, G. L. D.; FIALHO, A.; ZANUNCIO, J. C.; REIS JÚNIOR, R.; COSTA, C. A. Bagging tomato fruits: A viable and economical method of preventing diseases and insect damage in organic production. Florida Entomologist, v. 97, n. 1, p. 50-60, 2014. https://doi.org/10.1653/024.097.0106

LIMA, J.D.; ROZANE, D.E.; GOMES, E.N.; SILVA, S.H.M.G.; MORAES, W.S.; KLUGE, R.A. Chilling Prevention on Banana 'Nanica' in the Field with Bagging. Journal of Agricultural Science, v. 10, n. 3, 2018. https://doi.org/10.5539/jas.v10n3p122

MACHADO, J. C.; OLIVEIRA, J. A.; VIEIRA, M. G. G. C.; ALVES, M. C. Inoculação artificial de sementes de soja por fungos utilizando solução de manitol. Revista Brasileira de Sementes, v. 23, n. 2, p. 95-101, 2001. https://doi.org/10.17801/0101-3122/rbs.v23n2p95-101

MATSUMOTO, K.; KOBAYASHI, T.; KOUGO, T.; FUJTA, T.; SATO, S.; MORIGUCHI T. Sunlight Differentially Affects the Fruit Skin, Flesh, and Core Coloration of the Type 2 Red-Fleshed Apple 'Kurenainoyume': Optimization of Fruit Bagging Treatment. The Japanese Society for Horticultural Science, p. 1-12, 2018. https://doi.org/10.2503/hortj.OKD-120

MEENA, M. L.; GEHLOT, V. S.; MEENA, D. C.; KISHOR, S.; KISHOR, S.; KUMAR, S.; MEENA, J. K. Impact of biofertilizers on growth, yield and quality of tomato (Lycopersicon esculentum Mill.) cv. Pusa Sheetal. Journal of Pharmacognosy and Phytochemistry, v. 6, n. 4, p. 1579-1583, 2017.

MISHRA, K. K.; PATHAK, S.; CHAUDHARY, M. Effect of pre harvest spraying of nutrients and bagging with different colours of polythene on physico-chemical quality of rainy season guava (Psidium guajava L.) fruits cv. L-49. International Journal of Current Microbiology and Applied Sciences, v. 6, n. 9, p. 37973807, 2017. https://doi.org/10.20546/ijcmas.2017.609.469

MOURA, A. P.; MICHEREFF FILHO, M.; GUIMARAES, J. A. Manejo integrado de pragas do tomateiro para processamento industrial. Brasília, DF: Embrapa. 24 p. (Embrapa Hortaliças. Circular técnica, 129), 2014.

NAGAHARSHITHA, D.; VIMALA, B. A.; HALDANKAR, P.M. Effect of Bagging on Growth and Development of Mango (Mangifera indica L.) cv. Alphonso. Trends in Biosciences, v.7, n. 14, p. 1647-1649, 2014.

NANDI, P.; ROY, D.; DAS, K.; GHOSH, B.; KUNDU, S. Bagging technology for improving qualitative and quantitative traits of guava cv Khaja at different maturity stage. Environment and Ecology, v.34, n. 4, p. 2505$2508,2016$. 
NASIR, M. U.; HUSSAIN, S.; JABBAR, S. Tomato processing, lycopene and health benefits: A review. Science letters, v. 3, n. 1, p. 1-5, 2015.

PASTORI, P. L.; FILGUEIRAS, R. M. C.; OSTER, A. H.; BARBOSA, M. G.; SILVEIRA, M. R. S.; PAIVA, L. G. G. Postharvest quality of tomato fruits bagged with nonwoven fabric (TNT). Revista Colombiana de Ciencias Hortícolas, v. 11, n. 1, p. 80-88, 2017. https://doi.org/10.17584/rcch.2017v11i1.5839

PEIXOTO, J. V. M.; MORAES, E. R.; PEIXOTO, J. L. M.; NASCIMENTO, A. R.; NEVES, J. G. Tomato production: morphological aspects and physico-chemical properties of fruit. Revista Cientifica Rural, v. 19, n.1, 2017.

PERVEEN, R.; SULERIA, H. A. R.; ANJUM, F. M.; BUTT, M. S.; PASHA, I.; AHMAD, S. Tomato (Solanum lycopersicum) Carotenoids and Lycopenes Chemistry; Metabolism, Absorption, Nutrition, and Allied Health Claims-A Comprehensive Review. Critical Reviews in Food Science and Nutrition, v. 55, n. 7, 2015. https://doi.org/10.1080/10408398.2012.657809

PORTO, M.F.; SOARES, W. L. Modelo de desenvolvimento agrotóxicos e saúde: um panorama da realidade agrícola brasileira e propostas para uma agenda de pesquisa inovadora. Revista Brasileira de Saúde Ocupacional, v. 37, n. 125, 2012. https://doi.org/10.1590/S0303-76572012000100004

PRAMANIK, K.; MOHAPATRA, P. P. Tomato has a significant role inhuman nutrition because of its rich source of lycopene, minerals and B-carotene which are anti-oxidants and promote good health. Role of Auxin on Growth, Yield and Quality of Tomato - A Review. International Journal of Current Microbiology and Applied Sciences, v. 6, n. 11, p. 1624-1636, 2017. https://doi.org/10.20546/ijcmas.2017.611.195

RATHORE, A. C.; PAL, A. K. Pre-harvest fruit bagging improves fruit quality of mango in Doon valley. HortFlora Research Spectrum, v. 5, n. 1, p. 84-85, 2016.

REHMAN, A.; MALIK A. U.; ALI, H.; ALAM, M. W.; SARFRAZ, B. Preharvest Factors Influencing the Postharvest Disease Development and Fruit Quality of Mango.Journalof Environmental andAgriculturalSciences, v. 3, p. 42-47, 2015.

RUSIN, C.; BORBA, R. S.; ZANCHET, C. R.; COMIOTTO, A. Embalagens na proteção contra pragas de frutos de caquizeiro. Scientia Agraria Paranaensis, v. 14, n. suplemento, p. 305-309, 2015. https://doi.org/10.18188/1983-1471/sap.v14nsupp305-309

SHARMA, R. R.; REDDY, S. V. R.; JHALEGAR, M. J. Pre-harvest fruit bagging: a useful approach for plant protection and improved post-harvest fruit quality - a review. The Journal of Horticultural Science and Biotechnology, v. 89, n. 2, 2014. https://doi.org/10.1080/14620316.2014.11513055

SILVA, D. B.; CALEMAN, S. M. Q. Produção agrícola sustentável: análise de um sistema de produção de hortaliças em mato grosso do Sul. Qualit@s Revista Eletrônica, v. 17, n. 1, p.1-16, 2015.

VEDANA, M. B.; VIEIRA, E. T. V.; ITAVO, L. C. V Produção Integrada: Possibilidade de Alimentos Seguros e de Qualidade. Rev. FSA, v. 13, n.4, p. 115-133, 2016. https://doi.org/10.12819/2016.13.4.7

VENDRUSCOLO, E. P; LEAL, L. R. E.; SILVA, B. C. S.; CAMPOS, L. F. C.; MARTINS, A. P. B.; SELEGUINI, A. Material evaluation for bagging of cantaloupe melos. Ciência Rural, v. 47, n. 8, 2017. https://doi.org/10.1590/0103-8478cr20161016

VIUDA-MARTOS,M.; SANCHEZ-ZAPATA,E.;SAYAS-BARBERÁ,E.;SENDRA,E.; PÉREZ-ÁLVAREZ, J. A.;FERNÁNDEZ-LÓPEZ, J. Tomato and tomato by products. Human Health Benefits of Lycopene and Its Application to Meat Products: A Review. Critical Reviews in Food Science and Nutrition, v. 54, n. 8, 2014. https://doi.org/10.1080/10408398.2011.623799 
WANG, Y.; ZHANG, X.; WANG, R.; BAI, Y.; LIU, C.; YUAN, Y.; YANG, Y.; YANG, S. Differential gene expression analysis of 'Chili' (Pyrus bretschneideri) fruit pericarp with two types of bagging treatments.

Horticulture Research, v. 4, n. 17005, p. 1-10, 2017. https://doi.org/10.1038/hortres.2017.5

ZHANG, B. B.; GUO, J. Y.; MA, R. J.; CAI, Z. X.; YAN, J.; ZHANG, C. H. Relationship between the bagging microenvironment and fruit quality in 'Guibao' peach [Prunus persica (L.) Batsch]. The Journal of Horticultural Science and Biotechnology, v. 90, n. 3, p. 303-310, 2015.

https://doi.org/10.1080/14620316.2015.11513187 